\title{
Supplements:
}

\section{S1.1 Instrumental}

\section{S1.1.1 Diode Laser}

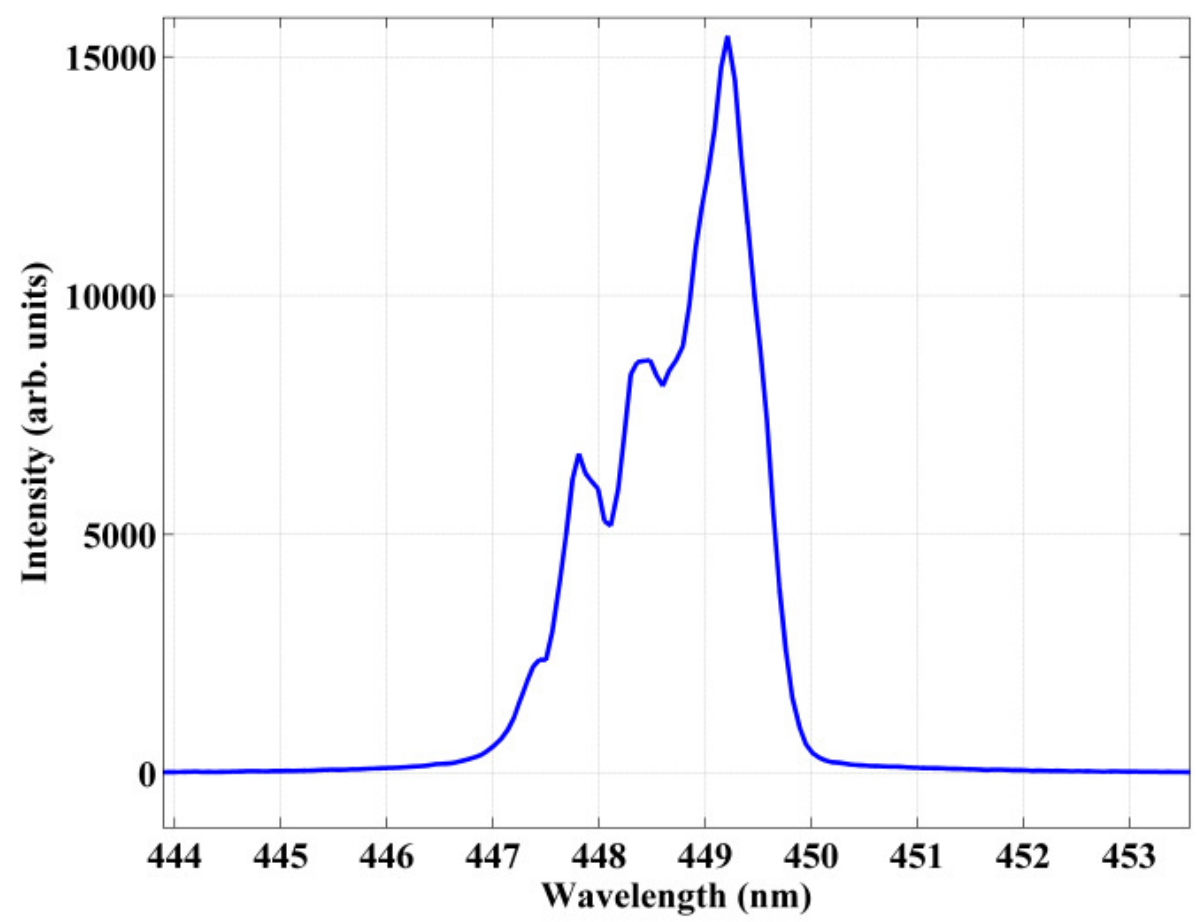

5 Fig. S1: Wavelength plot for the diode laser, operated with repetition rate of $5 \mathrm{MHz}$. The wavelength of the diode laser is measured with a spectrometer ${ }^{1}$.

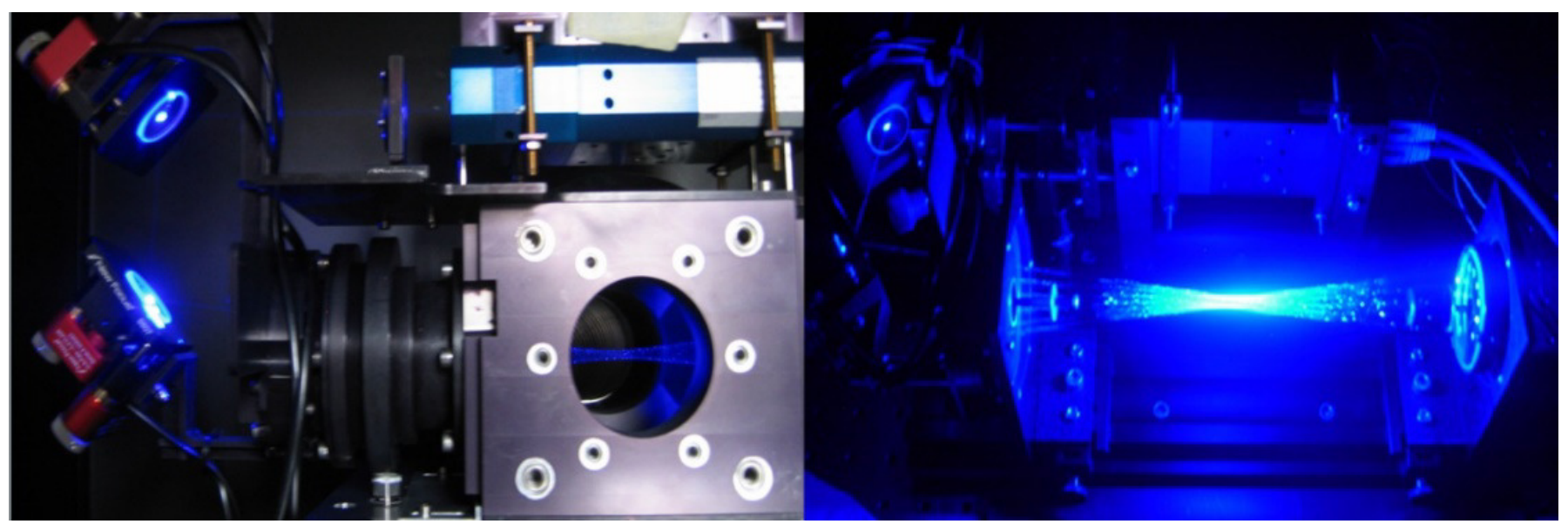

10 Fig. S2: Multiple passes of the laser beam are visible in the detection cell (left) and in between the Herriott cell's mirrors on an optical bench (right).

\footnotetext{
${ }^{1}$ HR4000 High-Resolution Spectrometer, Ocean Optics, USA
} 
S1.1.2 ON-OFF Laser cycle simulation

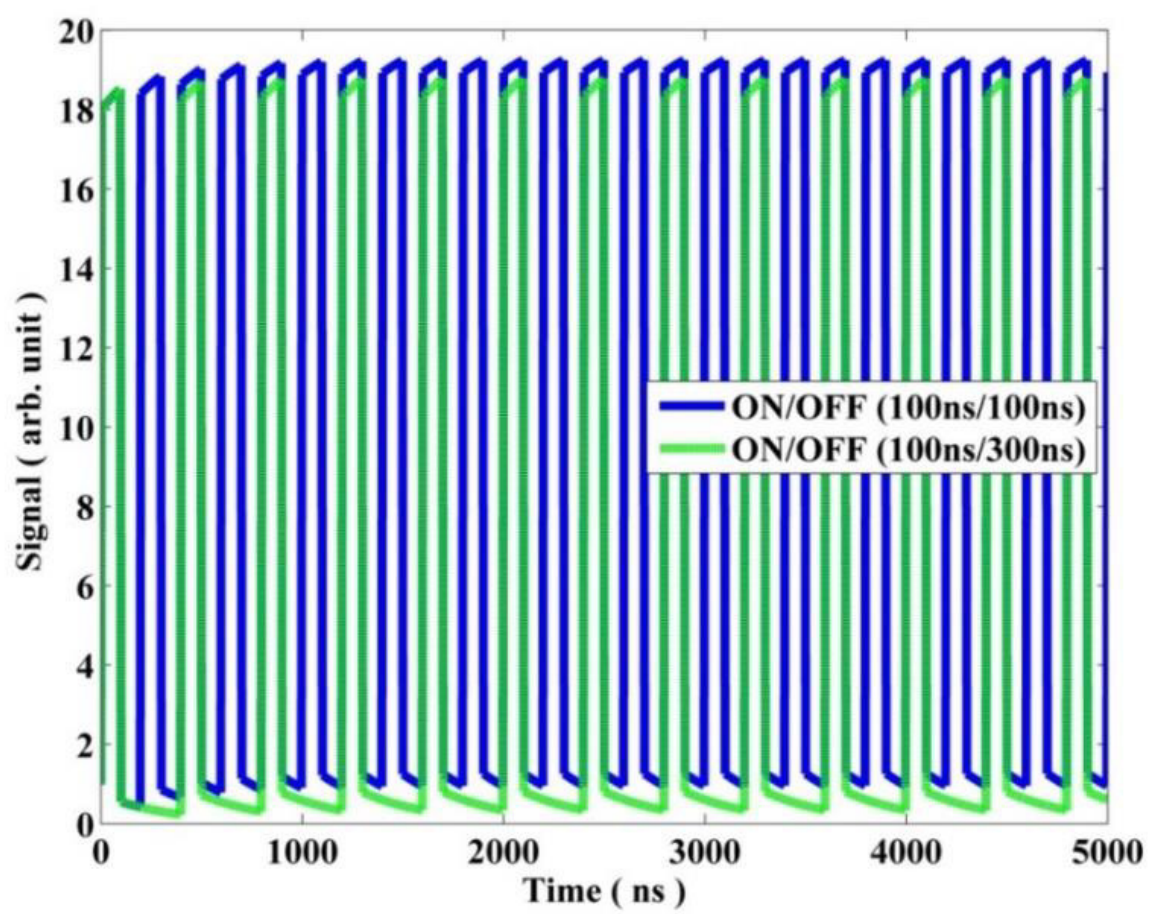

15 Fig. S3: Simulated ON/OFF cycles for operating the diode-lase

\section{S1.1.3 Laser ON/OFF cycle}

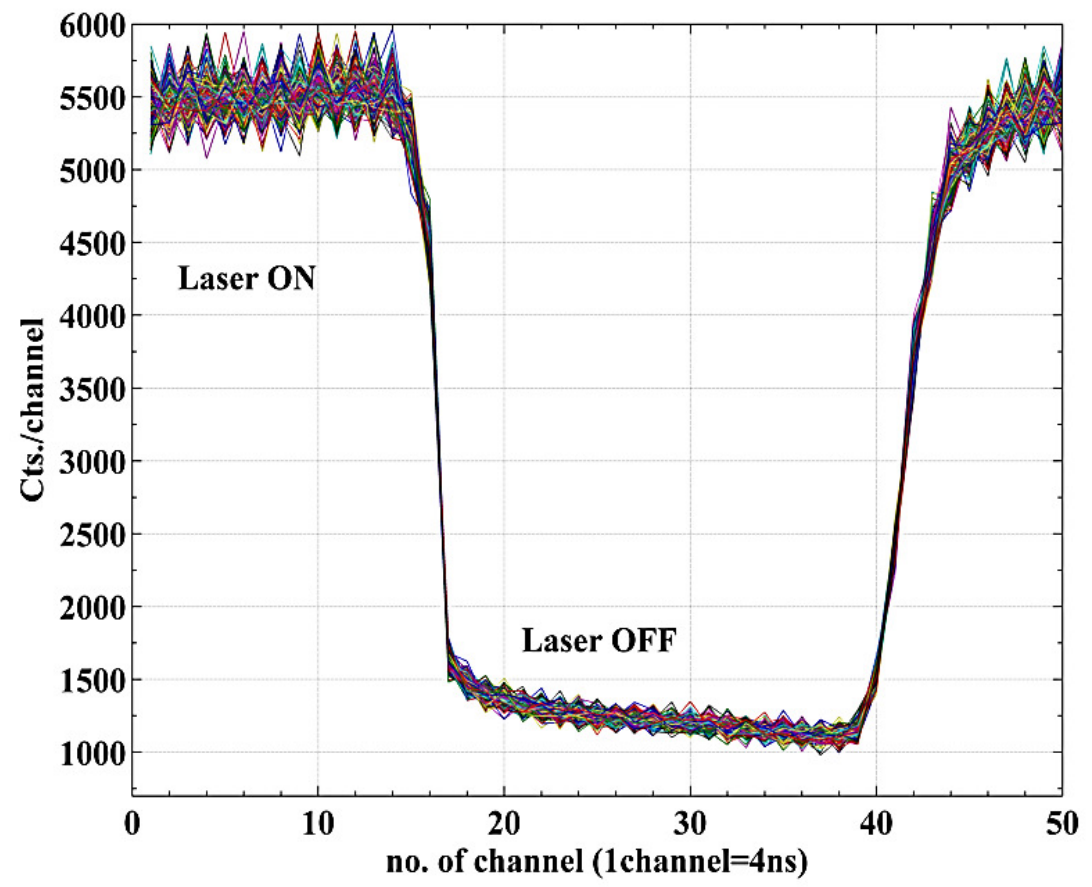

Fig. S4: 200ns on-off cycle of laser for a signal $\left(\sim 12 \mathrm{ppb}_{\mathrm{v}} \mathrm{NO}_{2}\right)$ [y-axis arb. unit] 


\section{S1.1.4 Reactions for calibration simulations}

Note; all reactions and rate coefficients from k1 to k64 are taken from (Atkinson et al., 2004) except k54 (temperature dependent) from (Sander et al., 2011). The impact of the difference between the JPL and IUPAC rate constant is less than $1 \%$ on our results.

$$
\mathrm{k} 1 \quad \text { : }
$$

$$
\mathrm{O}+\mathrm{O}_{2}
$$

$=\mathrm{O}_{3}$

$$
\text { k25: } \quad \mathrm{OH}+\mathrm{O}_{3}
$$

$\mathrm{k} 28: \quad \mathrm{HO}_{2}+\mathrm{O}_{3}$

$=\mathrm{HO}_{2}+\mathrm{O}_{2}$

$\mathrm{k} 31: \mathrm{O}+\mathrm{NO}$

$=\mathrm{OH}+\mathrm{O}_{2}+\mathrm{O}_{2}$;

k32 : $\mathrm{O}+\mathrm{NO}_{2}$

$=\quad \mathrm{NO}_{2}$;

$$
\text { k33 : }
$$$$
\mathrm{O}+\mathrm{NO}_{2}
$$

$=\quad \mathrm{O}_{2}+\mathrm{NO}$

30

k34 : $\mathrm{O}+\mathrm{NO}_{3}$

$=\quad \mathrm{NO}_{3}$;

k39 : $\quad \mathrm{OH}+\mathrm{HONO}$

$=\quad \mathrm{O}_{2}+\mathrm{NO}_{2} ;$

$\mathrm{k} 40: \quad \mathrm{OH}+\mathrm{HNO}_{3}$

$=\mathrm{H}_{2} \mathrm{O}+\mathrm{NO}_{2}$;

$\mathrm{k} 41: \quad \mathrm{OH}+\mathrm{HNO}_{4}$

$=\quad \mathrm{H}_{2} \mathrm{O}+\mathrm{NO}_{3}$;

$\mathrm{k} 42$ : $\quad \mathrm{OH}+\mathrm{NO}$

$=$ products;

$\mathrm{k} 43: \mathrm{OH}+\mathrm{NO}_{2}$

$=\mathrm{HONO}$;

$\mathrm{k} 44: \quad \mathrm{OH}+\mathrm{NO}_{3}$

$=\mathrm{HNO}_{3}$;

$\mathrm{k} 45: \quad \mathrm{HO}_{2}+\mathrm{NO}$

$=\quad \mathrm{HO}_{2}+\mathrm{NO}_{2}$;

$\mathrm{k} 46: \quad \mathrm{HO}_{2}+\mathrm{NO}_{2}$

$=\mathrm{OH}+\mathrm{NO}_{2}$;

$\mathrm{k} 47$ : $\quad \mathrm{HNO}_{4}$

$=\mathrm{HNO}_{4}$;

$$
\mathrm{k} 48: \quad \mathrm{HO}_{2}+\mathrm{NO}_{3}
$$$$
=\quad \mathrm{HO}_{2}+\mathrm{NO}_{2} \text {; }
$$

$=$ products;

k53 : $\quad \mathrm{NO}+\mathrm{NO}+\mathrm{O}_{2}$

$=\quad \mathrm{NO}_{2}+\mathrm{NO}_{2}$;

k54 : $\quad \mathrm{NO}+\mathrm{O}_{3}$

$=\quad \mathrm{NO}_{2}+\mathrm{O}_{2}$;

k55 : $\quad \mathrm{NO}+\mathrm{NO}_{2}$

$=\quad \mathrm{N}_{2} \mathrm{O}_{3}$;

k56 : $\quad \mathrm{N}_{2} \mathrm{O}_{3}$

$=\quad \mathrm{NO}+\mathrm{NO}_{2}$;$$
\mathrm{NO}+\mathrm{NO}_{3}
$$$$
=\quad \mathrm{NO}_{2}+\mathrm{NO}_{2} \text {; }
$$$$
\text { k58: } \quad \mathrm{NO}_{2}+\mathrm{O}_{3}
$$$$
=\quad \mathrm{NO}_{3}+\mathrm{O}_{2} \text {; }
$$

k59 : $\quad \mathrm{NO}_{2}+\mathrm{NO}_{2}$

$=\mathrm{N}_{2} \mathrm{O}_{4}$;

$\mathrm{k} 60$ : $\quad \mathrm{N}_{2} \mathrm{O}_{4}$

$=\quad \mathrm{NO}_{2}+\mathrm{NO}_{2}$;

$\mathrm{k} 61: \quad \mathrm{NO}_{2}+\mathrm{NO}_{3}$

$=\quad \mathrm{N}_{2} \mathrm{O}_{5}$;

$=\quad \mathrm{NO}_{2}+\mathrm{NO}_{3}$;

k63 : $\quad \mathrm{N}_{2} \mathrm{O}_{5}+\mathrm{H}_{2} \mathrm{O}$

$=\mathrm{HNO}_{3}+\mathrm{HNO}_{3}$;

k64 :

$\mathrm{N}_{2} \mathrm{O}_{5}+\mathrm{H}_{2} \mathrm{O}+\mathrm{H}_{2} \mathrm{O}$

$=\quad \mathrm{HNO}_{3}+\mathrm{H}_{2} \mathrm{O}$; 


\section{S1.1.5 Box Model simulated temperature and pressure effect on calibrator}
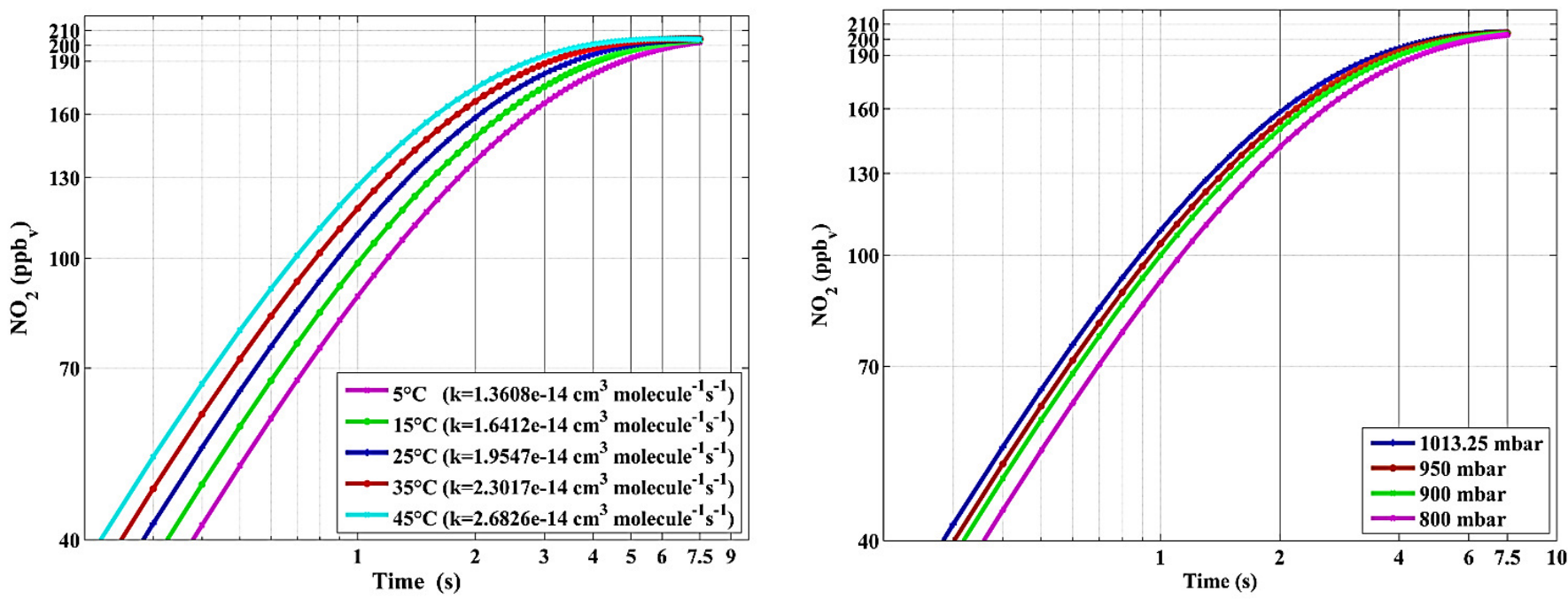

Fig. S5: In the left panel, $\mathrm{NO}_{2}$ concentrations inside the calibrator as a function of time based on different temperatures. While the right panel shows $\mathrm{NO}_{2}$ concentrations inside the calibrator as a function of time for different pressures (mbar or hPa).

\section{S1.1.6 Gas phase titration $\mathrm{NO}_{\mathrm{GPT}}$}

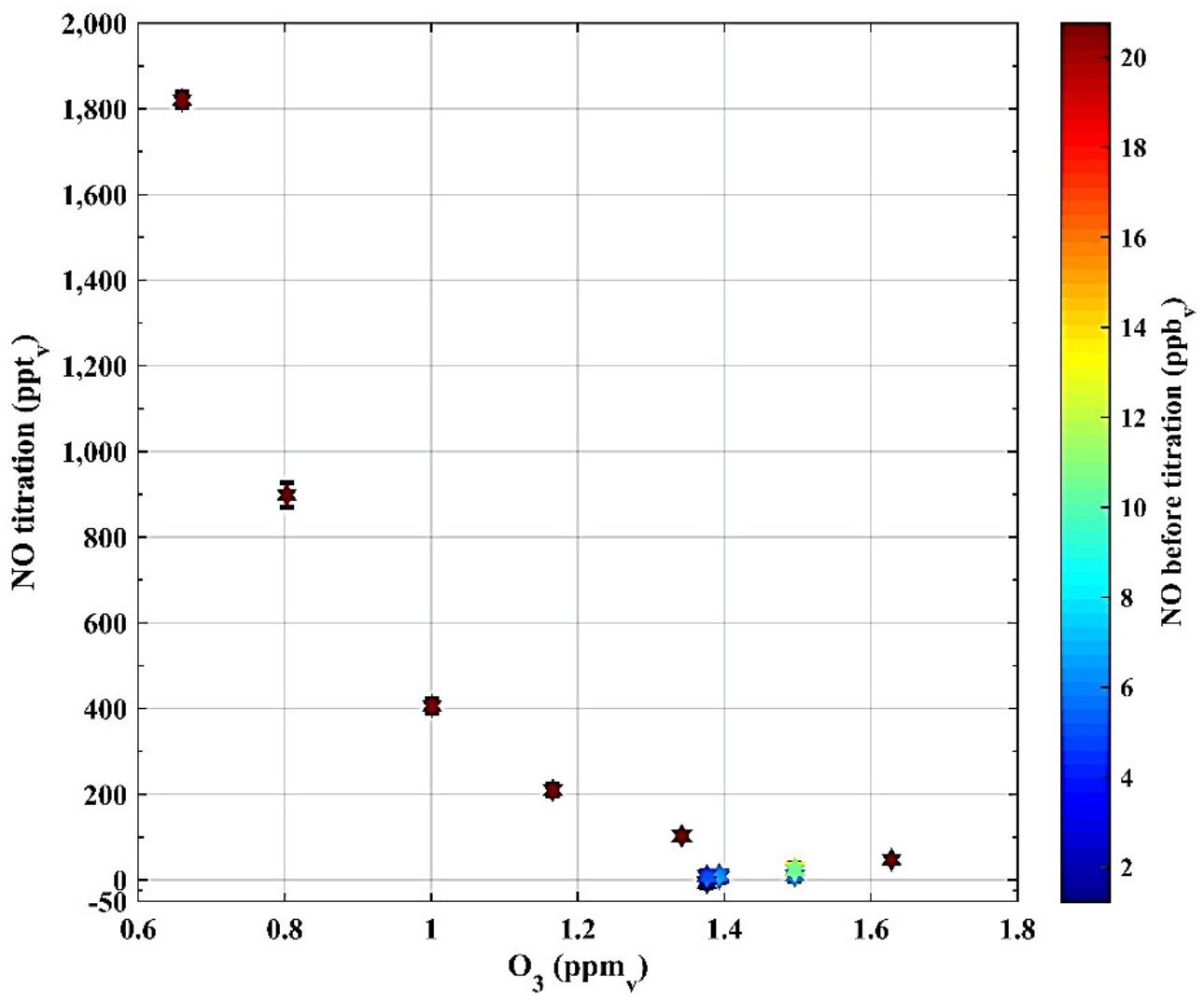

Fig. S6: $\mathrm{NO}_{\mathrm{GPT}}$ based on a CLD measurements as a function of the reaction chamber $\mathrm{O}_{3}$ mixing ratios. 


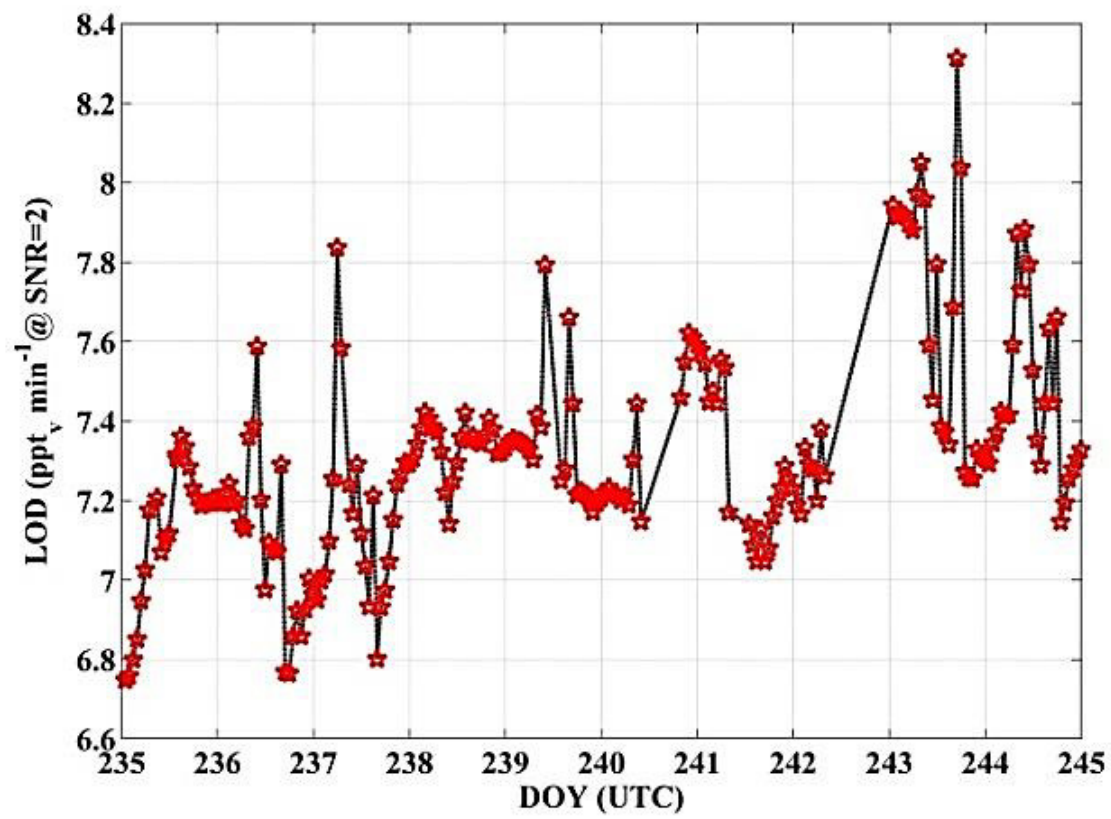

Fig. S7: An example for the limit of detection of GANDALF based on different calibrations, taken from an automated calibrated period of PARADE-2011 according to the Eq. 4 (Section 2.3) in the main draft.

\section{S1.2 PARADE-2011}

\section{S1.2.1 Air Mass Origin}
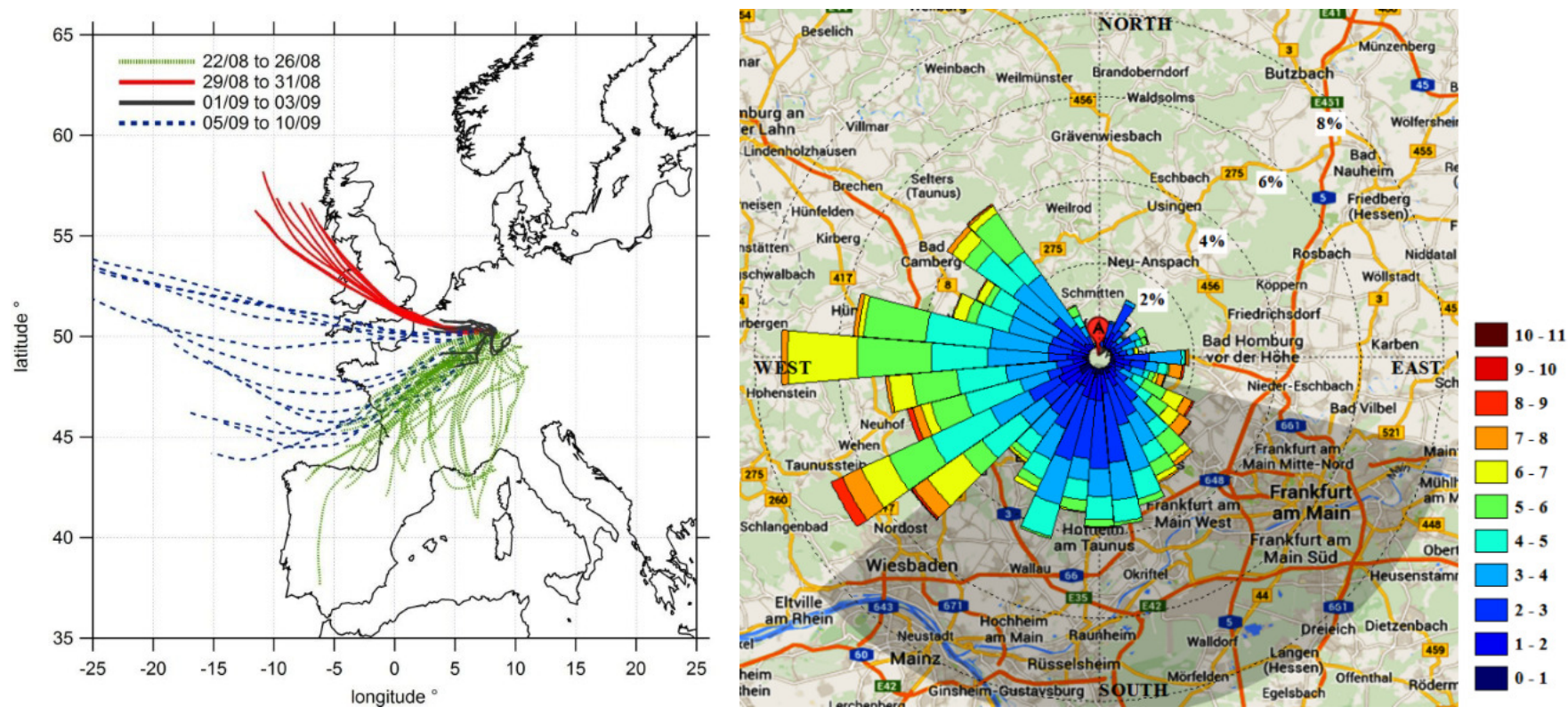

Fig. S8: Origin of air mass for PARADE-2011 [Figure is taken from Crowley, J., 2012 (left)]. Frequency distributions of wind directions with wind speed (colour-coded: wind speed in $\mathbf{m s}^{-1}$ ). [Google Map view (www.google.com/maps)]. While shaded area in R.H.S is showing possible anthropogenic influence from nearby cities. 


\section{S1.2.2 Frequency plot of $\mathrm{NO}_{2}$ measurements}

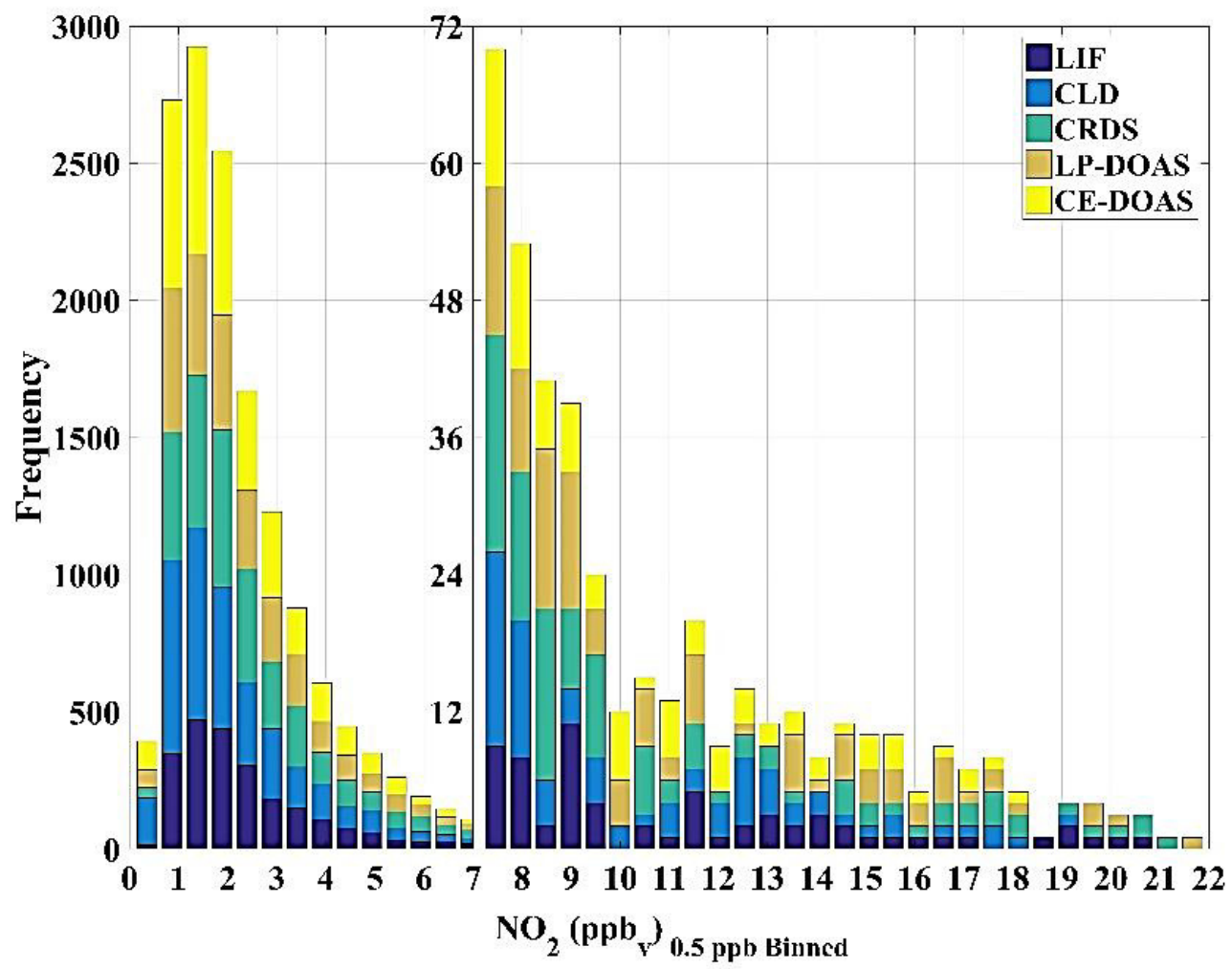

Fig. S9: Histogram of the distribution of the data for different $\mathrm{NO}_{2}$ measurements during PARADE 2011.

S1.2.3 Time series of $\mathrm{NO}_{2}$ measurements
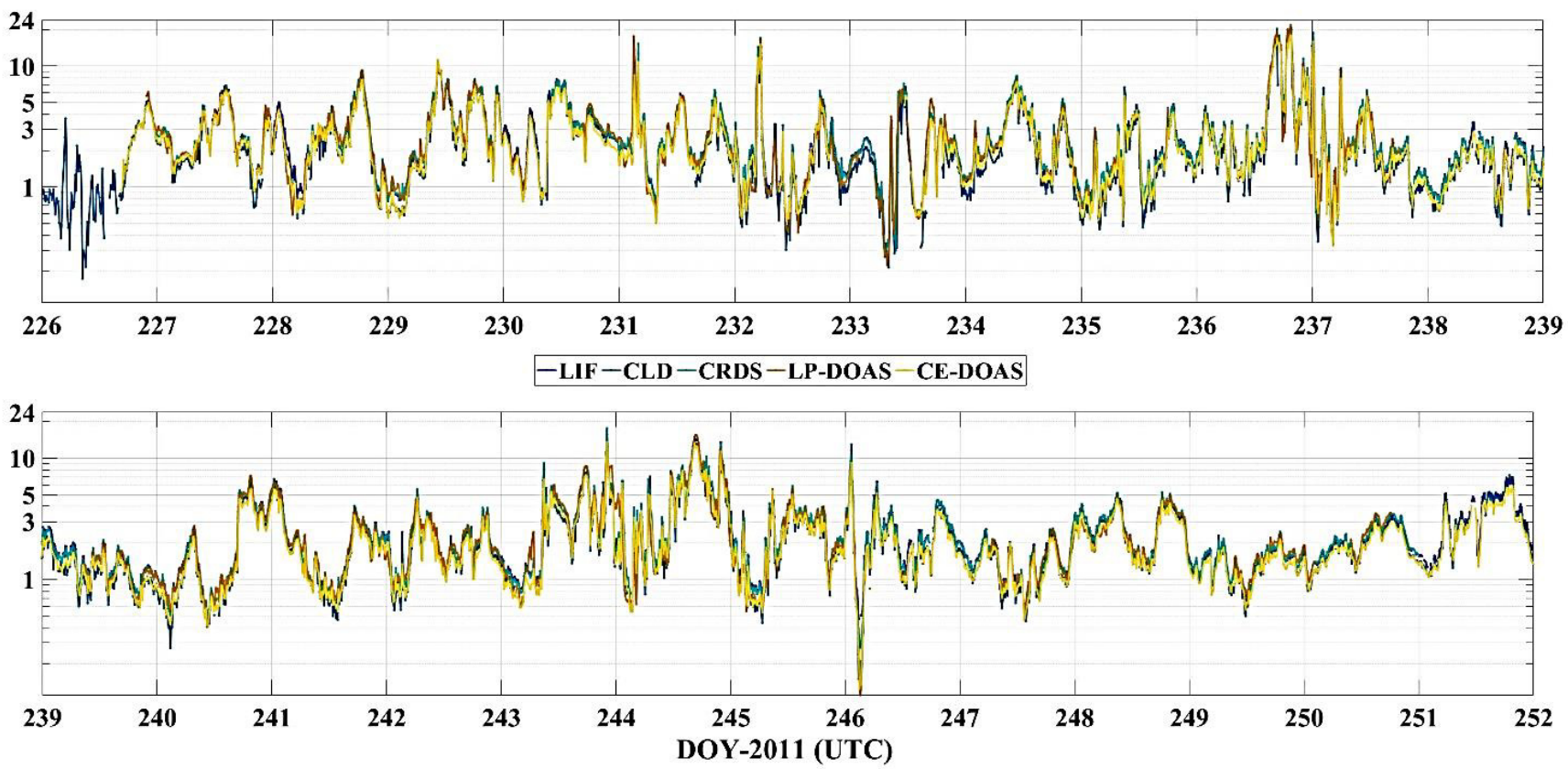

Fig. S10: PARADE 2011 time series (10 min. averages) of $\mathrm{NO}_{2}$ observations ( $\mathrm{y}$-axis in $\mathrm{ppb}_{\mathrm{v}}$ ) based on different instruments. 

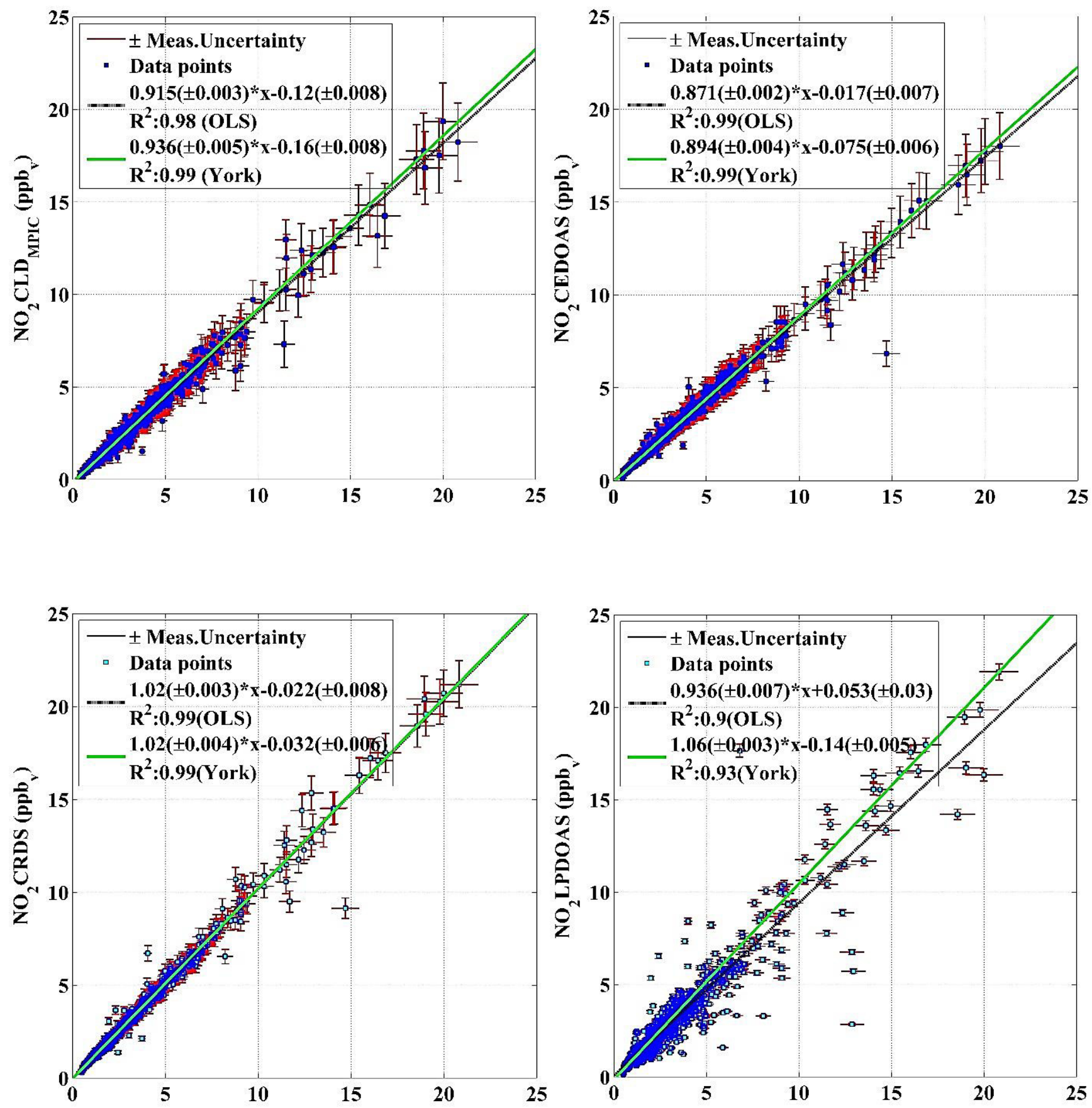

Fig. S11: The individual correlation of different $\mathrm{NO}_{2}$ instruments ( $y$-axis) versus GANDALF (x-axis) is shown for available 10 minutes data averages. The two different fitting procedures i.e. based on least square fit (Bevington and Robinson, 1992) and York method (York et al., 2004) are applied. 


\section{S1.2.5 $\mathrm{NO}_{2}$ Ratios Correlations}

This section is related to $\mathrm{NO}_{2}$ comparison for PARADE. A series of upcoming figures shows ratio (between all $\mathrm{NO}_{2}$ measurements and GANDALF) as a function of different observed quantities to see any systematic correlation. Each figure is a set of four subplots according to different instruments. Y-axis of figures below is shown as follow (with data colour to show sequence of upcoming figures for quick go through).

\begin{tabular}{|l|l|}
\hline LP-DOAS / GANDALF & CRDS / GANDALF \\
\hline CE-DOAS / GANDALF & CRD / GANDALF \\
\hline
\end{tabular}

Fig. S12: Ratios of different $\mathrm{NO}_{2}$ measurements with respect to GANDALF as a function of different measured species and parameters based on 10 minute averages.
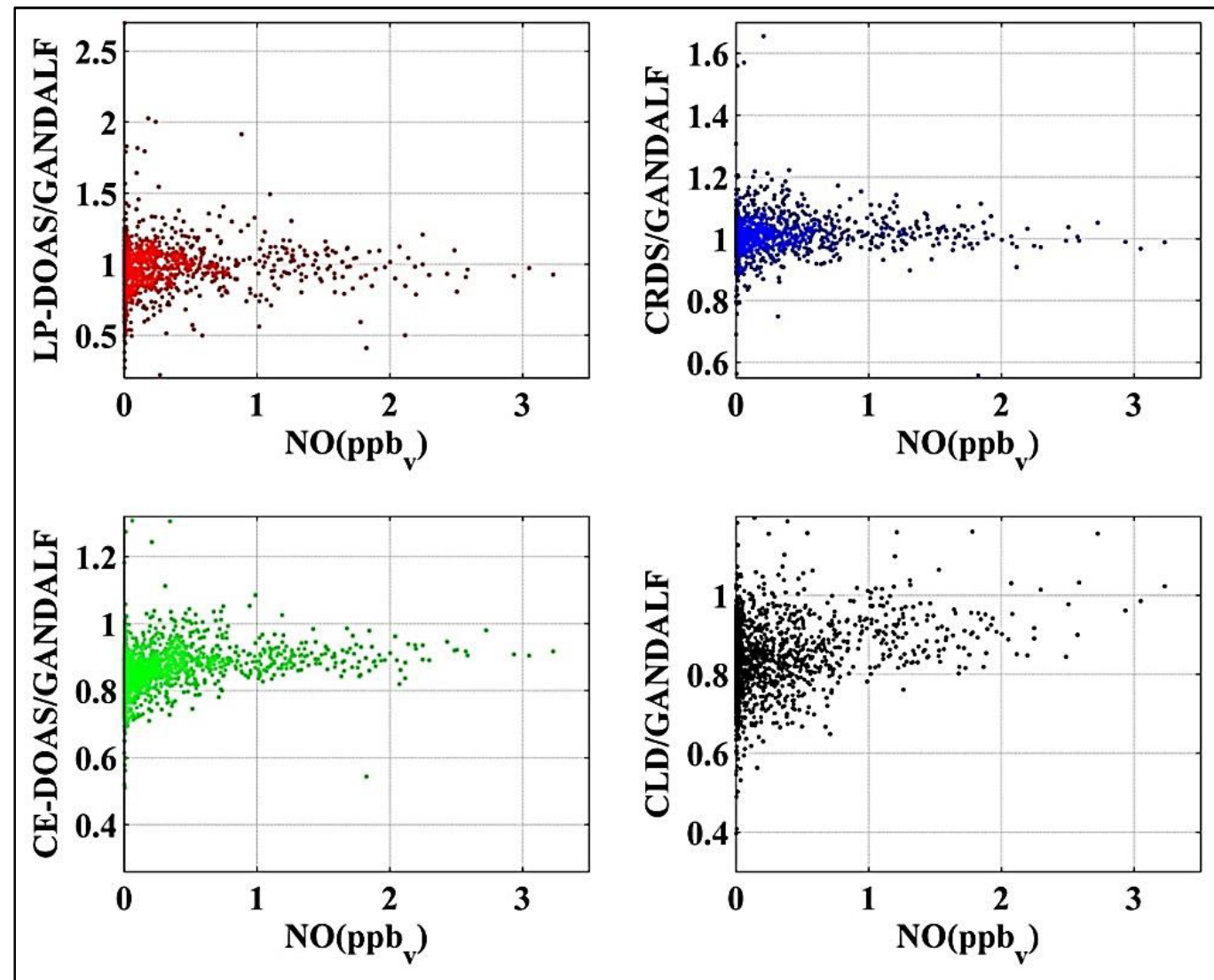

Fig. S12: continue 

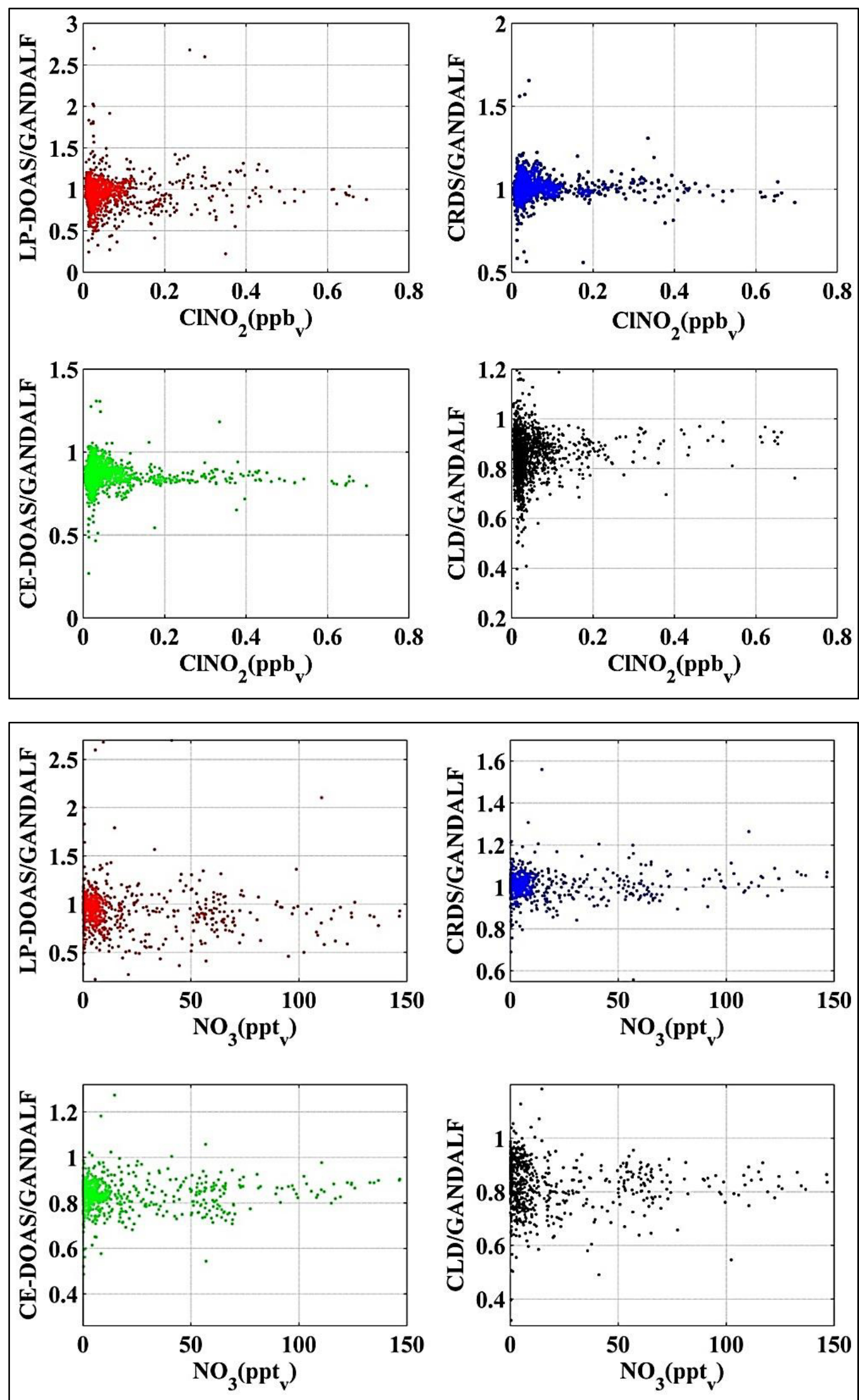

Fig. S12: continue 

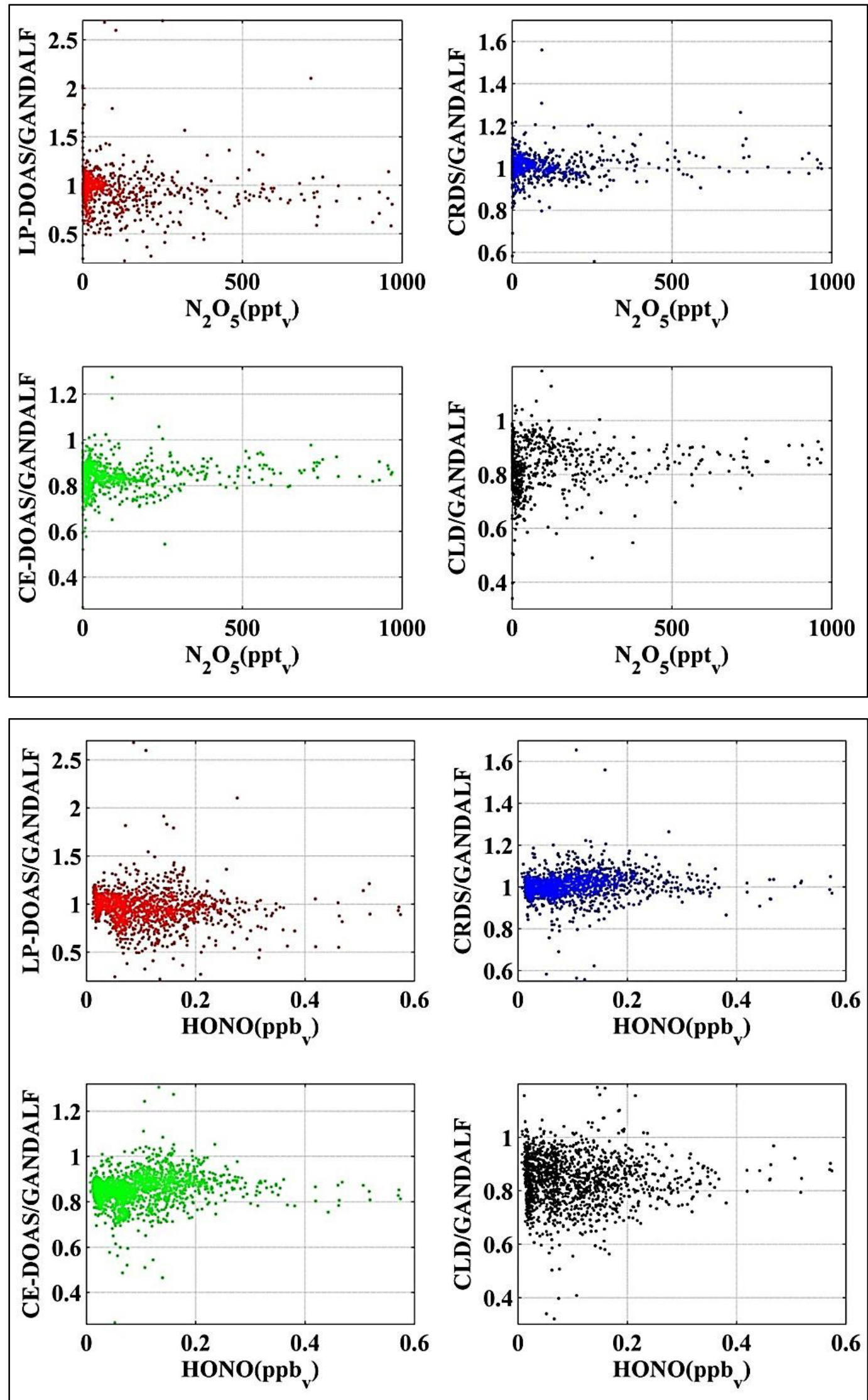

Fig. S12: continue 

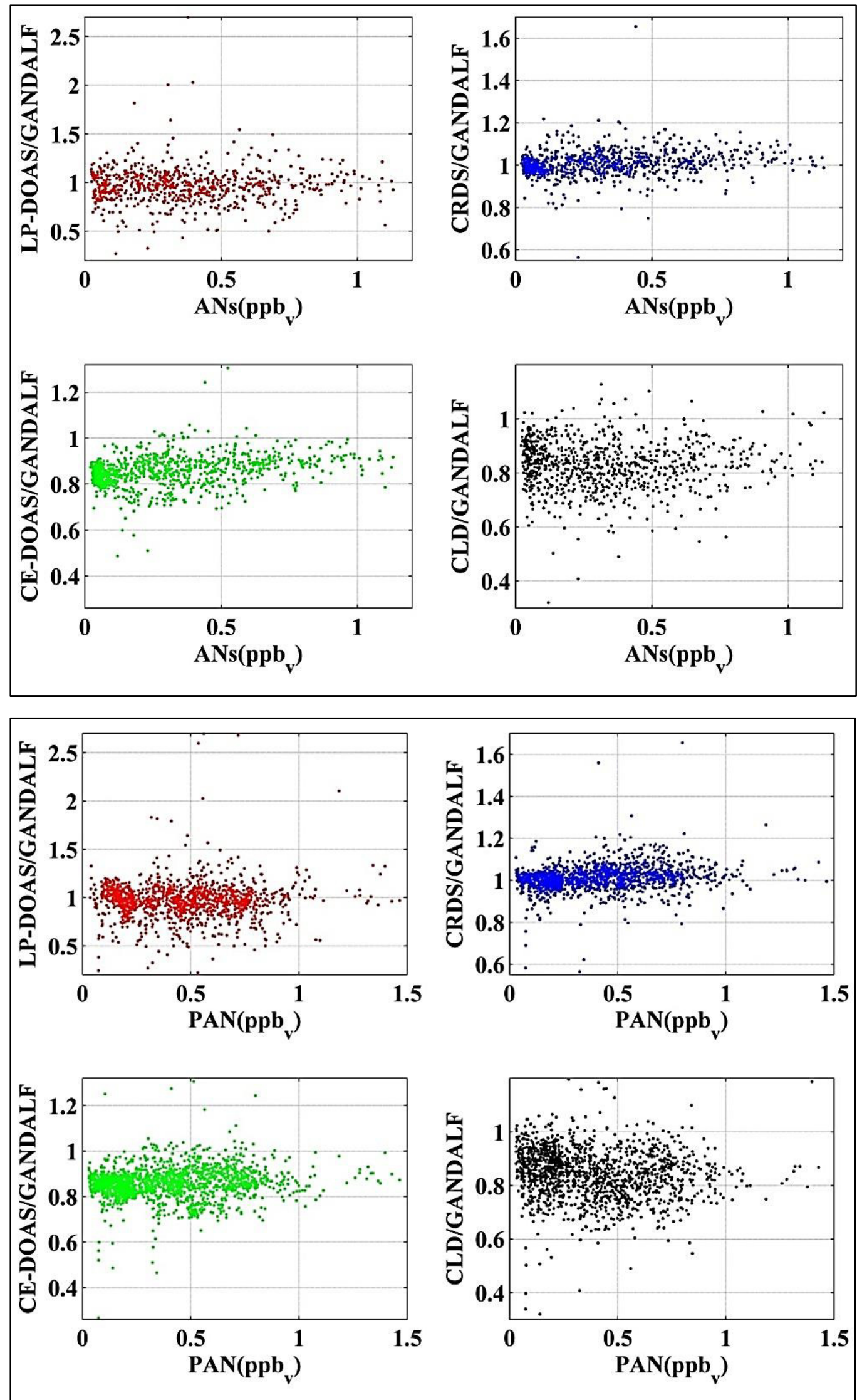

Fig. S12: continue 

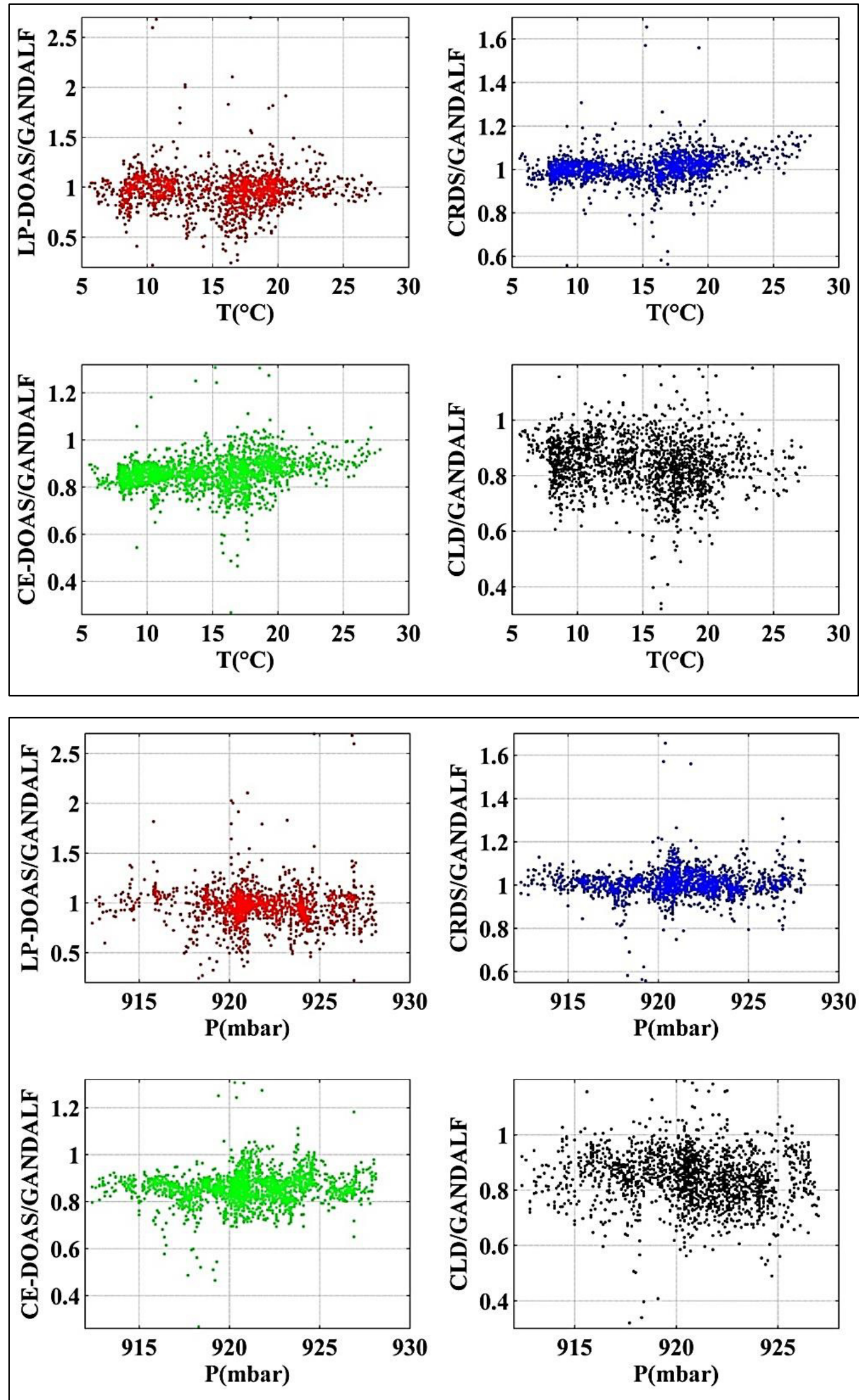

Fig. S12: continue 

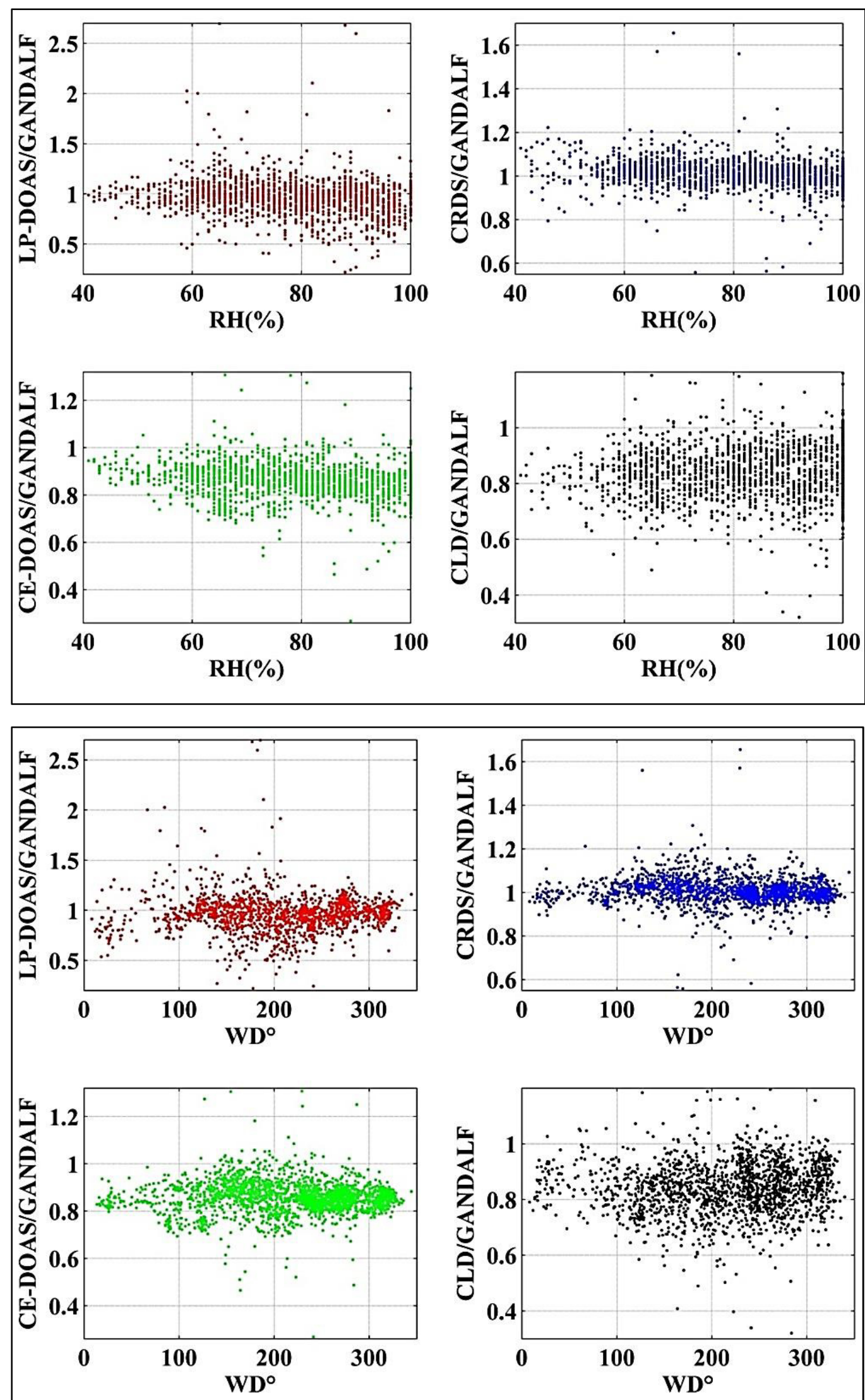

Fig. S12: continue 


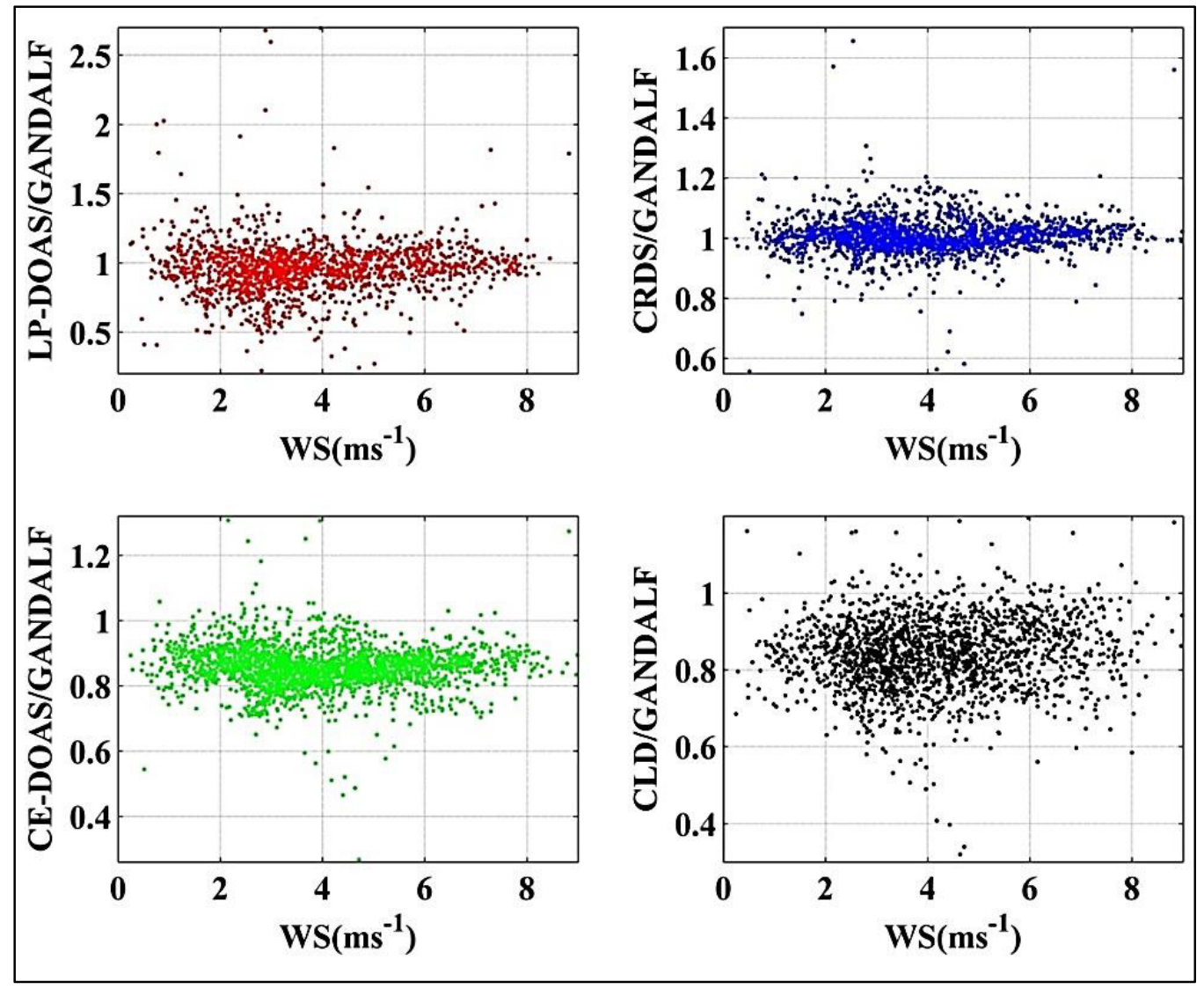

Fig. S12: continue

\section{S1.3 References}

Atkinson, R., Baulch, D. L., Cox, R. A., Crowley, J. N., Hampson, R. F., Hynes, R. G., Jenkin, M. E., Rossi, M. J., and Troe, J.: Evaluated kinetic and photochemical data for atmospheric chemistry: Volume I - gas phase reactions of $\mathrm{O}_{\mathrm{x}}, \mathrm{HO}_{\mathrm{x}}, \mathrm{NO}_{\mathrm{x}}$ and $\mathrm{SO}_{\mathrm{x}}$ species, Atmos Chem Phys, 4, 1461-1738, 2004.

Bevington, P. R., and Robinson, D. K.: Data reduction and error analysis for the physical sciences, 2nd ed., McGraw-Hill, New York, xvii, 328 p. pp., 1992.

Crowley, J., PArticles and RAdicals: Diel observations of the impact of urban and biogenic Emissions, PARADE data meeting at Max Planck Institute for Chemistry, Mainz, 10 ${ }^{\text {th }}$ May, 2012.

Sander, S. P., Abbatt, J., Barker, J. R., Burkholder, J. B., Friedl, R. R., Golden, D. M., Huie, R. E., Kolb, C. E., Kurylo, M. J., Moortgat, G. K., Orkin, V. L., and and Wine, P. H.: Chemical Kinetics and Photochemical Data for Use in Atmospheric Studies, in: JPL Publication 10-6, 2011.

York, D., Evensen, N. M., Martinez, M. L., and Delgado, J. D.: Unified equations for the slope, intercept, and standard errors of the best straight line, American Journal of Physics, 72, 367-375, Doi 10.1119/1.1632486, 2004. 